Relations industrielles

Industrial Relations

\title{
Canadian Labour in Crisis: Reinventing the Workers' Movement, By David Camfield, Halifax, N.S.: Fernwood Publishing, 2011, 168 pp., ISBN: 978-1-5526-6416-2.
}

\section{Alissa Mazar}

Volume 67, numéro 4, automne 2012

URI : https://id.erudit.org/iderudit/1013205ar

DOI : https://doi.org/10.7202/1013205ar

Aller au sommaire du numéro

Éditeur(s)

Département des relations industrielles de l’Université Laval

ISSN

0034-379X (imprimé)

1703-8138 (numérique)

Découvrir la revue

Citer ce compte rendu

Mazar, A. (2012). Compte rendu de [Canadian Labour in Crisis: Reinventing the Workers' Movement, By David Camfield, Halifax, N.S.: Fernwood Publishing, 2011, 168 pp., ISBN: 978-1-5526-6416-2.] Relations industrielles / Industrial Relations, 67(4), 731-733. https://doi.org/10.7202/1013205ar

Tous droits réservés (C Département des relations industrielles de l’Université Laval, 2012
Ce document est protégé par la loi sur le droit d'auteur. L'utilisation des services d’Érudit (y compris la reproduction) est assujettie à sa politique d'utilisation que vous pouvez consulter en ligne.

https://apropos.erudit.org/fr/usagers/politique-dutilisation/ 
de mettre l'accent sur les situations qui ont des limites de temps parfois très courtes et qui sont gérées de manière collective. La question du temps, dans les agences évènementielles, semble avoir des effets à la fois sur l'organisation des activités et sur les émotions. De plus, la dimension collective joue à plusieurs niveaux. Tout d'abord, il y a une dimension de jeu de pouvoir lors de la constitution du collectif, qui doit permettre la gestion collective de la dispersion et de ses effets. Toutefois, cela pose un enjeu particulier à l'insertion dans le collectif de travail et donne une plus grande importance au travail communicationnel. Ce travail, qui va soit faciliter la gestion des situations dispersives ou, au contraire, la rendre plus difficile, se déploie à deux niveaux. Premièrement, il est dirigé vers les collègues et nécessite beaucoup d'énergie du fait de la situation de mobilité dans laquelle chacun des acteurs se trouve. Deuxièmement, il est axé vers la relation client. Or le type de client et la forme que cette relation prend, en termes d'engagement, ont un effet important sur la fréquence d'apparition de situations dispersives.

Bien que l'auteure ait observé une diversité de situations de travail dispersives, elle constate des activités similaires dans chacun des cas, ce qui lui permet de formuler plusieurs apports sociologiques. Tout d'abord, il y a le constat de l'ambivalence des outils informatiques, qui sont à la fois aide à la gestion des situations dispersives et source de dispersion. II y a aussi les questions de coopération, qui s'avèrent à la fois complexes et nécessaires pour réaliser cette gestion. Enfin, son étude fait ressortir deux dimensions davantage individuelles. D'une part, l'importance de l'adéquation entre les compétences et les charges amène des réflexions, tant sur la formation que sur l'environnement de travail. D'autre part, du fait que la gestion de la dispersion nécessite un travail d'intégration de plusieurs engagements hétérogènes, la question de la consistance de la personne prend une importance particulière, c'est- à-dire que le travailleur, aux prises avec les situations de dispersion, doit faire un effort particulier pour articuler l'ensemble de ses actions. Il doit se coordonner lui-même, sous peine de paraître comme changeant d'idée régulièrement et non sincère vis-à-vis de ses interlocuteurs.

En terminant, cet ouvrage aborde la question de la dispersion au travail sous I'angle de l'activité. En choisissant cette approche, Caroline Datchary ouvre une nouvelle avenue qui lui permet de poser un regard neuf sur un ensemble de métiers et de situations de travail susceptibles d'engendrer de la dispersion. Bien que ne traitant pas explicitement des questions plus globales de santé au travail que ses travaux soulèvent, elle pose un premier jalon, précis et utile, à la compréhension de l'activité nécessaire face à certaines situations de travail. Pour l'instant, charge est laissée au lecteur d'en tirer les conclusions pour l'agir organisationnel ou les innovations sociales que cette activité nécessiterait de mettre en place ou de concevoir dans les entreprises.

\section{Sébastien Bruère}

Université Laval

\section{Canadian Labour in Crisis: Reinventing the Workers' Movement}

By David Camfield, Halifax, N.S.: Fernwood Publishing, 2011, 168 pp., ISBN: 978-1-55266416-2.

David Camfield's Canadian Labour in Crisis: Reinventing the Workers' Movement falls within the larger literature documenting the current state of labour movements in affluent democracies. Going beyond numerical analyses of union membership and density rates, Camfield's text adds to the qualitative discussion by examining the internal and external power transformations of Canadian unions. Despite Canadian union density incurring a slow decline from its peak of 41.8 percent in 1984 to 29.5 percent in 2009, Camfield suggests that density does not translate into power (p. 14). 
Camfield argues that Canadian unions "are becoming less effective for unionized workers and less significant for the working-class as a whole" (p. 6). This trend is concerning since workers' movements, and more specifically union organizations, are an ethically crucial space where workers collectively pursue labour's interests. Unions are a social good from the life-ground ethical perspective for Camfield, increasing the individual ability to acquire "life-requirements" based on physical, socio-cultural and "free-time" (p. 94). From these premises, Camfield supposes the importance of understanding the declining power of the Canadian workers' movement.

The workers' movement appearing insignificant in Canada results from the institutionalization and bureaucratization of unions and their subsequent detachment from workers' interests. To address declining political power, Camfield urges the reinvention of the union movement from below, which would challenge: the increasing concessions made by union officialdom, decreasing democracy in unions, increasing distance from low-wage, nonunionized, private sector workers and workers of colour, few youth union activists and ties with political parties which do not oppose neoliberal restructuring.

Camfield points to contract business unionism as fostering union decline, which results in a lack of labour engagement and militancy by shifting focus to collective bargaining and a cooperative approach with employers. As a result of contract business unionism, there has been a lessening of collective action and an increase in individual grievances. Also, unions have become increasingly concerned with preserving themselves as an institution through concessionary relations with employers rather than prioritizing working-class interests.

The historical forces that Camfield cites in the conversion of unionism to a deradicalized bureaucracy are the loss of structures to effectively dissent, which began with the institutionalization of Canadian unions in the 1940 s as a response to wartime strikes. These transformations include employer friendly "responsible unionism," neoliberal capitalist restructuring, the decline of the left and the increase of neoliberal minded union officialdom. Indeed, as presently structured, unions do not facilitate the creation of working-class solidarity. Critiquing efforts to reform the workers' movement from above, Camfield argues that this strategy further disengages workers. Reinventing the workers' movement from below for Camfield is crucial, fostering democratic social movement unionism based on anti-capitalist, anti-racist, feminist, working-class politics.

Camfield's text falls into the theoretical paradigm of the "neoliberal offensive thesis" by focusing on union destabilization due to neoliberal globalization. However, Camfield assumes causal links as lessening the power of the Canadian workers' movement. For instance, Camfield argues that neoliberal restructuring causes a decrease in union power. However, no causal mechanism is established, while the particular usage of "neoliberalism" is not operationalized. Does the presence of neoliberal policy universally create a decline in the power of workers' movements? And if so, what are the particular policies and mechanisms within neoliberalism that contribute to this decline? Examining the implementation of trade agreements, like NAFTA, would be helpful in pointing to actual linkages. The use of "neoliberalism" as a catchphrase obscures a nuanced understanding of the specific variables that may contribute to a decline in the viability of workers' movements.

To thoroughly address the current position of the Canadian workers' movement, Camfield's text, which depends on qualitative statements of union officials, activists and anecdotal examples, would benefit from the breadth of empirical research which examines the varied impacts "neoliberalism" has on the power of labour unions. 
This would also be helpful in curbing the use of the term "neoliberal" founded on universal application and convergence, which Camfield's text seems to suggest. Additionally, an examination of union decline based on sector and how union tactics differ accordingly would offer more specificity concerning the occurrence of how, where and the extent of union power decline.

Although I believe Camfield's critique of the Canadian labour movement is well founded, Camfield overgeneralizes by homogenizing the workers' movement. Conducting a comparative analysis between specific union practices would expose the differing levels of union power and worker militancy corresponding to their historical trajectories, union policies and campaigns. Moreover, to offer grand claims regarding the current state of the Canadian workers' movement, aggregate level data and analysis are required to demonstrably measure the significant changes in power that Camfield professes. Finally, Camfield states that the interests of capital are antithetical to workers' well-being. It is thus suggested that the workers' movement employ an anti-capitalist stance, dismissing social democratic means to negotiating capital and labour relations as "futile and dangerous" (p. 137). It is necessary to flesh out this argument since its validity cannot be assumed and must be continually articulated through explicit reasoning and logic.

Nonetheless, Camfield convincingly argues for the importance of the workers' movement in Canada as a force that provides physical and social goods. The text points to significant factors within and outside unions that potentially contribute to the current weakness of the Canadian workers' movement. Providing working solutions for the democratic, grassroots, worker-based revitalization of social movement unionism in Canada, Camfield's accessible text is a helpful guide for activists and academics alike.

\footnotetext{
Alissa Mazar

McGill University
}

\section{Risques psychosociaux : quelle réalité, quels enjeux pour le travail ?}

Coordonné par François Hubault, Toulouse : Octarès éditions, 2011, 195 p., ISBN : 978-2915346-89-3.

Ce livre publié dans la collection « Le travail en débats » regroupe plusieurs conférences présentées les 8, 9 et 10 juin 2009 dans le cadre d'un séminaire organisé par le département Ergonomie et Écologie humaine de I'Université Paris I. De fait, ce département coordonne à chaque année, depuis environ vingt ans, un séminaire portant sur un aspect controversé du travail, tout en plaçant l'ergonomie au centre du débat. En 2009, le thème abordé fut les risques psychosociaux (RPS).

Afin de faire le tour de la question, de nombreux universitaires, chercheurs et praticiens ont été invités à faire des présentations lors du séminaire. Le coordonnateur de l'ouvrage, François Hubault, précise dans I'avant-propos que deux grandes questions ont été privilégiées. D'abord, qu'entend-on au juste par l'expression " risques psychosociaux » (RPS) ? Est-ce un nouveau mot pour décrire une vieille réalité ou s'agit-il d'un nouveau phénomène et, si tel est le cas, quelle en est la nature particulière ? Ensuite, quelles questions ces " risques psychosociaux » posent-ils aux sciences sociales en général et à l'ergonomie en particulier ? Les contributions des auteurs abordent donc I'une ou l'autre de ces questions, et parfois les deux à la fois.

Dans le premier chapitre, Cristofari cherche à mieux cerner la réalité des RPS en abordant différentes façons de les définir, de même que les modèles théoriques, en particulier ceux de Karasek et de Siegrist, qui permettent d'en saisir l'étiologie. Les grandes enquêtes menées en France pour en comprendre l'ampleur sont également évoquées dans cette contribution. Sans donner de définition précise, cette auteure précise tout de même que les RPS englobent finalement le stress au travail, le harcèlement psychologique et sexuel, les 